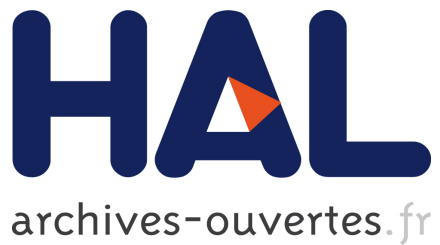

\title{
The release of phosphorus from heavily fertilized soils to dilute electrolytes: effect of soil properties
}

Antonio Delgado, José Torrent

\section{To cite this version:}

Antonio Delgado, José Torrent. The release of phosphorus from heavily fertilized soils to dilute electrolytes: effect of soil properties. Agronomie, EDP Sciences, 1999, 19 (5), pp.395-404. $<$ hal-00885939>

\section{HAL Id: hal-00885939 \\ https://hal.archives-ouvertes.fr/hal-00885939}

Submitted on 1 Jan 1999

HAL is a multi-disciplinary open access archive for the deposit and dissemination of scientific research documents, whether they are published or not. The documents may come from teaching and research institutions in France or abroad, or from public or private research centers.
L'archive ouverte pluridisciplinaire $\mathbf{H A L}$, est destinée au dépôt et à la diffusion de documents scientifiques de niveau recherche, publiés ou non, émanant des établissements d'enseignement et de recherche français ou étrangers, des laboratoires publics ou privés. 


\title{
The release of phosphorus from heavily fertilized soils to dilute electrolytes: effect of soil properties
}

\author{
Antonio Delgado ${ }^{\mathrm{a}^{*}}$, José Torrent ${ }^{\mathrm{b}}$ \\ ${ }^{a}$ Departamento de Ciencias Agroforestales, Universidad de Sevilla, EUITA, Ctra. Utrera km 1, 41013 Sevilla, Spain \\ b Departamento de Ciencias y Recursos Agrícolas y Forestales, Universidad de Córdoba, Apdo. 3048, 14080 Córdoba, Spain
}

(Received June 1998, accepted 12 March 1999)

\begin{abstract}
Soils heavily fertilized with P can contribute to the enrichment of $\mathrm{P}$ in surface runoff and can accelerate the eutrophication of streams and lakes. To describe this enrichment, information is needed on the capacity and rate of $\mathrm{P}$ release from soils. Thus, we carried out laboratory studies in which the release of $\mathrm{P}$ to a dilute electrolyte $\left(0.002 \mathrm{M} \mathrm{CaCl}_{2}\right)$ was characterized in 12 widely different, heavily fertilized European soils. We studied: a) long-term P release under 'static' conditions (in soil suspensions allowed to settle and left undisturbed for long periods); and b) short-term P release under 'turbulent' conditions (rapidly stirred suspensions). The relationships between the amount of $P$ released under static conditions and the solution/soil ratio $(W)$ and time differed widely among soils. These differences were the probable result of differences in the content of the relatively soluble metal phosphates (capable of buffering $\mathrm{P}$ solution in the $10^{-6}-10^{-5} \mathrm{M}$ concentration range) and in the $\mathrm{P}$ adsorption capacity of the soils. The ratio between $\mathrm{P}$ released at $340 \mathrm{~d}$ for $W=10000$ and $\mathrm{P}$ exchanged isotopically at $1 \mathrm{~d}$ was generally $>2$ in soils rich in soluble phosphates and with a high degree of surface saturation with $\mathrm{P}$, while it was $<1$ in soils with low surface saturation with $\mathrm{P}$ (acid soils with high $\mathrm{P}$ adsorption capacity). In soils rich in organic matter, the amounts of dissolved organic $\mathrm{P}$ and molybdate-reactive $\mathrm{P}$ released were comparable. Under turbulent conditions, the amount of $P$ released after $2 \mathrm{~h}$ of soil-electrolyte contact ranged between 7 and $27 \%$ of the $P$ released at $340 \mathrm{~d}$ under static conditions. This stresses the importance that surface runoff and initial stream transport have in loading surface waters with $P$. The release of $P$ under turbulent conditions was slower in acid sandy soils, where poorly crystalline $\mathrm{Fe}$ and $\mathrm{Al}$ oxides were the most important $\mathrm{P}$ adsorbents. (ㄷ Inra/Elsevier, Paris.)
\end{abstract}

phosphorus release / eutrophication / phosphorus dissolution / phosphorus desorption

Résumé - Sols surfertilisés : libération de phosphore dans des électrolytes dilués. Les eaux de ruissellement provenant de sols surfertilisés peuvent conduire à l'eutrophisation des rivières et des lacs. Il est alors nécessaire de disposer de méthodes permettant de prévoir les vitesses de libération des phosphates à partir des particules de terre. Des études ont été entreprises au laboratoire avec douze sols européens surfertilisés mais de caractéristiques physico-chimiques très

Communicated by Emmanuel Frossard (Lindau, Switzerland)

* Correspondence and reprints

adelgado@cica.es 
différentiées. La mise en solution du phosphore a été étudiée dans des solutions de $\mathrm{CaCl}_{2} 0,002 \mathrm{M}$ en faisant varier le rapport solution-sol, W, de 10 à 10000 . Ces études ont été conduites dans deux directions: a) libération sur le long terme ( $340 \mathrm{j})$ et en conditions statiques; b) libération sur le court terme ( $2 \mathrm{~h})$ et en conditions turbulentes. La quantité de $P$ passée en solution en conditions statiques croît avec $\mathrm{W}$ et le temps de contact entre le sol et les solutions. La libération de $\mathrm{P}$ est fonction du contenu de phosphates solubles et de la capacité de rétention du P par les sols. Les quantités de $\mathrm{P}$ passées en solution pour $\mathrm{W}=10000$ et durant $340 \mathrm{j}$ sont élevées pour les sols pour lesquels la quantité de phosphore soluble et le degré de saturation sont élevés; elles sont faibles lorsque le degré de saturation du sol par les phosphates est peu élevé. Cette dernière situation est celle des sols acides à teneur élevée en matière organique; de plus, dans ces sols une fraction significative du phosphore passant en solution est sous forme organique. Dans les conditions turbulentes, les quantités de phosphore transférées dans la phase liquide en $2 \mathrm{~h}$ varient de $7 \%$ à $27 \%$ des quantités transférées à 340 $\mathrm{j}$ en conditions statiques. En conséquence la participation du phosphore durant la phase de transfert en surface vers les cours d'eau peut contribuer significativement à l'augmentation de la concentration du phosphore dans les eaux. La mise en solution du phosphore dans les conditions turbulentes semble plus lente dans les sols dont la rétention des phosphates serait contrôlée par des oxydes métalliques mal cristallisés. (@ Inra/Elsevier, Paris.)

eutrophisation / phosphate / libération / dilution / adsorption

\section{Introduction}

High rates of phosphorus $(\mathrm{P})$ applied as fertilizer, manure or waste materials have resulted in an accumulation of $\mathrm{P}$ in many agricultural soils of developed countries. This contributes to the P loads of continental waters and thus eutrophication [9, 10]. The loss of soil $P$ to water occurs by surface runoff and subsurface flow. The relative contributions of these two processes depend on climate, soil type, crop and soil management, and soil P status $[4,27]$. Losses by surface runoff usually predominate in soils having surface horizons with high $\mathrm{P}$ sorption capacity, particularly when soil slope is high $[1,28]$. In this case, pathways of $P$ transport are dominated by surface runoff [21], either in solution or in eroded particles [11]. Generally, particulate $\mathrm{P}$ consititutes the major portion (75-90\%) of $\mathrm{P}$ transported in runoff from cultivated land [18].

In surface runoff, the release of $\mathrm{P}$ from soil particles to water occurs during changing turbulent conditions that are difficult to reproduce in the laboratory, although they may be approximated by continuous shaking or stirring of dilute soil suspensions. Under these conditions, the release of $\mathrm{P}$ to the solution can be described by:

$$
Q=k P_{\mathrm{o}} W^{a} t^{b}
$$

where $Q$ is the amount of $\mathrm{P}$ released, $P_{\mathrm{o}}$ is the amount of extractable $P$ in soil given by some known extraction method (e.g. resin), $W$ is the solution/soil ratio, $t$ is time and $k, a$ and $b$ are constants [19]. The effects of $W$ and $t$ (through the values of their exponents) have been found to depend on soil properties [17].

The soil particles transported by surface runoff can eventually be deposited as bottom sediments in lakes, reservoirs or other slow moving waters. The rate of $\mathrm{P}$ release from, or sorption to the solid phase at the sediment/water interface is slow, since it mainly depends on diffusion and convective movements. In summary, the pattern and rate of release of soil $\mathrm{P}$ to the water in contact with the soil is likely to be influenced by the hydraulic conditions (static or turbulent) of the soil-water system.

The objective of this work was to evaluate, by means of laboratory experiments, the effect of soil properties on soil $\mathrm{P}$ release patterns to dilute electrolytes under a variety of simulated static and turbulent conditions. Twelve widely different, heavily fertilized soils from the European Union were used for this purpose, as a means of identifying major $P$ release patterns. 


\section{Materials and methods}

\subsection{Soils}

Twelve soils were sampled in 1992, which were representative of different agricultural areas of the European Union. Samples of the $A_{p}$ horizons $(0-20 / 30 \mathrm{~cm})$ were air-dried and ground/sieved to $<2 \mathrm{~mm}$ before analysis. The methods used in the physical, chemical and mineralogical analyses, and the corresponding results have been reported by Barberis et al. [3], Delgado and Torrent [8] and Ruíz et al. [16]. The latter authors have also reported in detail the different $P$ forms these soils contain. Tables $I$ and $I I$ give a summary of the most relevant soil properties, which range widely. As a result of application of $\mathbf{P}$ fertilizers at doses in excess of plant $P$ uptake, all the soils show soil $P$ test values more than twice as large as the recommended critical level for optimum crop growth. We used an index of the potential $\mathrm{P}$ adsorption capacity of soils, which can be obtained from the amounts of the active $\mathrm{Fe}$ and $\mathrm{Al}$ forms (crystalline oxides, poorly crystalline oxides and metalo-organic complexes) as estimated from citrate/bicarbonate/dithionite-extractable $\mathrm{Fe}$ $\left(\mathrm{Fe}_{\mathrm{d}}\right)$ and oxalate-extractable $\mathrm{Fe}$ and $\mathrm{Al}\left(\mathrm{Fe}_{\mathrm{o}}\right.$ and $\left.\mathrm{Al}_{\mathrm{o}}\right)$. Such a $\mathrm{P}$ adsorption capacity index (PACI) is defined as:

$$
\mathrm{PACI}=\mathrm{Fe}_{0}+\mathrm{Al}_{\mathrm{o}}+\left(\mathrm{Fe}_{\mathrm{d}}-\mathrm{Fe}_{0}\right) / 5
$$

and is expressed in mmol $\mathrm{kg}^{-1}$. In order to define this index we assumed that the $\mathrm{P}$ adsorption capactiy per $\mathrm{mol}$ of $\mathrm{Fe} / \mathrm{Al}$ is about five times lower in crystalline $\mathrm{Fe}$ oxides (estimated by $\mathrm{Fe}_{d}-\mathrm{Fe}_{0}$ ) than in amorphous oxides (estimated by $\mathrm{Fe}_{0}+\mathrm{Al}_{0}$ ) [25].

\section{2. $P$ release to dilute electrolytes}

The release of $P$ under static conditions (intended to simulate the release taking place at the surface of a sediment at the bottom of a water body) was studied at solution/soil ratios $(W)$ of $10,30,100,300,800,2500$, 5000 and 10000 . The amount of soil used was $3 \mathrm{~g}$ for $W=10,1 \mathrm{~g}$ for $W=30-5000$ and $0.5 \mathrm{~g}$ for $W=10000$. The background electrolyte was $0.002 \mathrm{M} \mathrm{CaCl}_{2}$, similar in ionic strength to many continental waters [23]. Soil and solution were placed in polyethylene bottles and three drops of toluene were added to avoid microbial activity. The bottles were kept at $298 \pm 1 \mathrm{~K}$ and were shaken $(1 \mathrm{~min})$ only at the start of the experiment and immediately before each sampling. Samples of the suspensions were taken using a $10-\mathrm{cm}^{3}$ syringe at $1,2,3,6$, $10,20,40,70,110,150,200,250$ and $340 \mathrm{~d}$. The samples were filtered using a $0.22-\mu \mathrm{m}$ cellulose nitrate filter. Total P (TP) [2] and molybdate-reactive P (MRP)

Table I. Selected soil properties ${ }^{\mathrm{a}}$.

\begin{tabular}{|c|c|c|c|c|c|c|c|c|c|}
\hline Soil & $\mathrm{pH}\left(\mathrm{H}_{2} \mathrm{O}\right)$ & Organic C & Clay & $\begin{array}{l}\mathrm{Fe}_{\mathrm{d}}^{\mathrm{b}} \\
\left(\mathrm{g} \mathrm{kg}^{-1}\right)\end{array}$ & $\mathrm{Fe}_{0}{ }^{\mathrm{h}}$ & $\mathrm{Al}_{\mathrm{d}}{ }^{\mathrm{b}}$ & $\mathrm{Al}_{0}{ }^{\mathrm{b}}$ & \multicolumn{2}{|c|}{$\begin{array}{cc}\text { PACI }^{\mathrm{c}} & \mathrm{ISSP}^{\mathrm{d}} \\
\left(\mathrm{mmol} \mathrm{kg}^{-1}\right) & \left(\mathrm{mg} \mathrm{mmol}^{-1}\right)\end{array}$} \\
\hline Dl & 7.0 & 24 & 200 & 6.0 & 1.9 & 0.7 & 1.4 & 101 & 2.0 \\
\hline D2 & 7.2 & 13 & 150 & 8.6 & 3.0 & 1.0 & 1.2 & 118 & 0.8 \\
\hline D3 & 5.9 & 9 & 10 & 2.2 & 1.6 & 0.9 & 0.9 & 64 & 2.3 \\
\hline E1 & 8.7 & 7 & 170 & 4.0 & 0.7 & 0.4 & 0.5 & 43 & 1.2 \\
\hline E2 & 8.3 & 9 & 450 & 2.8 & 0.8 & 0.5 & 1.0 & 58 & 0.5 \\
\hline E3 & 7.5 & 8 & 350 & 15.8 & 1.1 & 0.7 & 1.2 & 117 & 0.3 \\
\hline G3 & 6.1 & 39 & 50 & 14.4 & 7.7 & 8.0 & 6.1 & 388 & 0.4 \\
\hline G6 & 5.3 & 33 & 50 & 12.7 & 5.5 & 3.5 & 3.9 & 269 & 0.6 \\
\hline G9 & 6.1 & 29 & 70 & 14.8 & 5.5 & 4.2 & 4.2 & 287 & 0.5 \\
\hline II & 5.9 & 12 & 110 & 9.6 & 4.8 & 0.9 & 0.8 & 132 & 0.6 \\
\hline 12 & 6.6 & 4 & 90 & 11.5 & 4.0 & 1.3 & 0.9 & 132 & 1.4 \\
\hline I3 & 8.2 & 12 & 300 & 6.1 & 1.7 & 1.0 & 1.7 & 109 & 0.5 \\
\hline
\end{tabular}

a Determined by the methods described by Barberis et al. [3] and Delgado and Torrent [8].

${ }^{\mathrm{h}}$ Abbreviations: $d$, citrate/bicarbonate/dithionite-soluble; $o$, acid oxalate-soluble.

' Phosphate adsorption capacity index $=\left(\mathrm{Fe}_{0}+\mathrm{Al}_{0}\right)+\left(\mathrm{Fe}_{\mathrm{d}}-\mathrm{Fe}_{0}\right) / 5$.

${ }^{\mathrm{d}}$ Index of surface saturation by phosphate $=\mathrm{IEP}_{1} / \mathrm{PACI}\left(\mathrm{IEP}_{1}=\mathrm{P}\right.$ exchanged isotopically at 1 day $)$. 
Table II. Phosphorus forms ${ }^{\mathrm{a}}$.

\begin{tabular}{|c|c|c|c|c|c|c|c|c|}
\hline \multirow[b]{2}{*}{ Soil } & \multirow[b]{2}{*}{ Total $P^{c}$} & \multirow[b]{2}{*}{ Organic $\mathrm{P}$} & \multirow[b]{2}{*}{ Inorganic $\mathrm{P}$} & \multicolumn{5}{|c|}{$\mathrm{P}$ fractions using sequential extraction ${ }^{\mathrm{b}}$} \\
\hline & & & & $\mathrm{NaOH}$ & $\mathrm{CB}$ & CBD & $\mathrm{HCl}$ & $\mathrm{IEP}_{1}^{\mathrm{d}}$ \\
\hline DI & 1168 & 205 & 672 & 88 & 306 & 207 & 177 & 200 \\
\hline D2 & 890 & 221 & 402 & 129 & 132 & 160 & 110 & 99 \\
\hline D3 & 988 & 25 & 744 & 650 & 58 & 41 & 52 & 144 \\
\hline $\mathrm{E} 1$ & 1400 & 100 & 1049 & 7 & 234 & 127 & 947 & 51 \\
\hline E2 & 706 & 36 & 500 & 4 & 91 & 40 & 437 & 26 \\
\hline E3 & 333 & 98 & 82 & 25 & 37 & 66 & 16 & 36 \\
\hline G3 & 1920 & 715 & 651 & 636 & 57 & 121 & 149 & 135 \\
\hline G6 & 1593 & 597 & 585 & 627 & 35 & 146 & 123 & 154 \\
\hline G9 & 1331 & 550 & 441 & 481 & 47 & 71 & 52 & 138 \\
\hline I1 & 709 & 10 & 406 & 354 & 52 & 121 & 48 & 72 \\
\hline 12 & 1067 & 64 & 595 & 393 & 114 & 285 & 115 & 182 \\
\hline I3 & 1035 & 10 & 543 & 14 & 171 & 129 & 424 & 58 \\
\hline
\end{tabular}

a Determined by the methods described by Barberis et al. [3] and Delgado and Torrent [8].

${ }^{\mathrm{b}}$ Method of Olsen and Sommers [15]. Abreviations: CB, citrate/bicarbonate; CBD, citrate/bicarbonate/dithionite.

${ }^{c}$ Total $\mathrm{P}$ exceeds the sum of organic and inorganic $\mathrm{P}$ since it includes residual $\mathrm{P}$ that is not dissolved in the determination of inorganic P.

${ }^{\mathrm{d}} \mathrm{P}$ exchanged isotopically at 1 day.

[12] were analysed in the filtrate. For $\mathbf{P}$ solution concentrations $<10^{-6} \mathrm{M}$, a cell with a $10-\mathrm{cm}$ path was used. The difference between TP and MRP was assumed to be due to dissolved organic P (DOP).

The experiments of $P$ release under turbulent conditions were intended to simulate the soil-rainwater interaction in runoff and initial stream transport. For this purpose, suspensions with $W$ values of $30,100,300$, $800,2500,5000$ and 10000 were prepared, since different $W$ values can be considered as an approximation of the intensity of runoff-soil interaction [19]. The soil suspensions were continuously stirred $\left(20 \mathrm{rad} \mathrm{s}^{-1}\right)$ in a polyethylene beaker. Samples of the suspension were taken at times between $1 \mathrm{~min}$ and $2 \mathrm{~h}$ and analysed as described above.

\subsection{Statistical analyses}

The non-linear potential equations used to describe $P$ release as a function of $W$ and $t$ were fitted to the experimental data by means of the Simplex procedure (CoHort Software, Minneapolis, MN, USA). To compare the values of the exponents corresponding to two data sets a dummy variable $Z$ was defined, which was $Z=0$ for the first and $Z=1$ for the second data set. Then, the least squares were estimated by means of a joint model where the two multiplicative effects, i.e. the coefficients of $W Z$ and $t Z$ were considered. Values of these coefficients that differed significantly from 0 , as evaluated by the t-test, were considered to indicate significant differences in the exponents affecting $W$ and $t$.

\section{Results and discussion}

For the purpose of this work, the soils can be grouped into calcareous (E1, E2 and I3), slightly acid (D1, D2, E3 and I2), acid with high organic matter content (G3, G6 and G9) and acid sandy (D3 and I1). Table II shows that the total phosphorus content is high in most soils $(>1000 \mathrm{mg}$ $\mathrm{P} \mathrm{kg}^{-1}$ ), and that the relative proportions of the various $\mathrm{P}$ forms differ widely among soils. This is particularly clear from the data of the sequential extraction (table $I I$ ), which is based on the use of $\mathrm{NaOH}$ (to remove non-occluded $\mathrm{Al}-$ and Fe-bound 
Table III. P released under static conditions.

\begin{tabular}{|c|c|c|c|c|c|c|}
\hline Soil & $\begin{array}{c}S^{\mathrm{a}} \\
(\mathrm{mg} \mathrm{P} \mathrm{kg-1})\end{array}$ & $a^{\mathrm{a}}$ & $b^{\mathrm{a}}$ & $R^{2}$ & $\begin{array}{c}\text { P released at } 340 \text { days for } \\
W=10000\left(Q_{340}\right)\left(\mathrm{mg} \mathrm{P} \mathrm{kg}^{-1}\right)\end{array}$ & $Q_{340} / \mathrm{IEP}_{1}$ \\
\hline D1 & 8.20 & $0.33 b$ & $0.21 \mathrm{a}$ & $0.93^{* * *}$ & 572 & 2.86 \\
\hline D2 & 1.97 & $0.33 b$ & $0.25 b$ & $0.92^{* * *}$ & 165 & 1.67 \\
\hline D3 & 8.16 & $0.29 \mathrm{a}$ & $0.23 \mathrm{ab}$ & $0.97^{* * *}$ & 418 & 2.90 \\
\hline $\mathrm{E} 1$ & 3.07 & $0.31 \mathrm{ab}$ & $0.21 \mathrm{a}$ & $0.96^{* * * *}$ & 167 & 3.27 \\
\hline E2 & 0.18 & $0.48 \mathrm{~cd}$ & $0.29 c$ & $0.96^{* * *}$ & 92 & 3.54 \\
\hline E3 & 0.04 & $0.65 f$ & $0.22 \mathrm{a}$ & $0.89^{* * * *}$ & 65 & 1.81 \\
\hline $\mathrm{G} 3$ & 0.03 & $0.69 \mathrm{~g}$ & $0.23 \mathrm{ab}$ & $0.83^{* * *}$ & 66 & 0.49 \\
\hline G6 & 0.28 & $0.51 \mathrm{~d}$ & $0.23 \mathrm{ab}$ & $0.92^{* * *}$ & 123 & 0.80 \\
\hline G9 & 0.12 & $0.57 \mathrm{e}$ & $0.24 \mathrm{~b}$ & $0.91^{* * *}$ & 95 & 0.69 \\
\hline I1 & 0.08 & $0.58 \mathrm{e}$ & $0.35 \mathrm{~d}$ & $0.98^{* * *}$ & 142 & 1.97 \\
\hline 12 & 5.38 & $0.31 \mathrm{ab}$ & $0.2 \mathrm{la}$ & $0.95^{* * * *}$ & 313 & 1.72 \\
\hline I3 & 0.37 & $0.47 \mathrm{c}$ & $0.23 \mathrm{ab}$ & $0.96^{* * *}$ & 113 & 1.95 \\
\hline
\end{tabular}

\footnotetext{
"Constants of equation $Q=S W^{a} t^{b}$, where $W$ is the solution/soil ratio and $t$ is time in days. Values followed by the same letter in the same column are not significantly different $(P<0.05)$.
}

$\mathrm{P}$ ), citrate/bicarbonate (to remove the $\mathrm{P}$ adsorbed by carbonates in the preceding extraction), citrate/bicarbonate/dithionite (to remove $\mathrm{P}$ occluded within the $\mathrm{Fe}$ oxides) and $\mathrm{HCl}$ (to remove $\mathrm{Ca}$ bound $\mathrm{P}$ ). These and other data led Delgado [7] and Ruíz et al. [16] to conclude that: a) precipitated calcium phosphates seem to be the dominant form in calcareous soils (E1, E2 and I3) and in the slightly acid and limed soils (D1 and D2); b) phosphate adsorbed on $\mathrm{Fe}$ and $\mathrm{Al}$ oxides and on organically complexed $\mathrm{Fe}$ and $\mathrm{Al}$ predominates in the acid soils rich in organic matter (G3, G6 and G9); c) some complex $\mathrm{Fe}-\mathrm{Al}-\mathrm{Ca}$ phosphates (D3 and I2) and phosphate adsorbed on oxides and silicate clays (E3 and I1) predominate in the other acid soils.

\subsection{Long-term $P$ release under static conditions}

The amount of MRP released in static systems depended on the solution/soil ratio $(W)$ and time $(t)$, according to an equation analogous to equation (1), which can be written as:

$$
Q=S W^{a} t^{b}
$$

The values of the constants in equation (3) are shown in table III. It should be noted that this equation was derived, and is valid, for the $10<W<10000$ and $1<t$ (days) $<340$ ranges. Constant $a$ defines the effect of the dilution of soil particles [17] and $b$ measures the curvature of the $\mathrm{P}$ release-time relationship.

Values of $a$ in equation (3) are significantly different from zero, which indicates that the solution/soil ratio $(W)$ has a marked effect on $\mathrm{P}$ release. This is illustrated in figure 1, which shows the amount of MRP released as a function of $W$ at $340 \mathrm{~d}$. Probably, this effect is partly due to the experimental setting adopted. Even though the soil was only in contact with a limited portion of the total solution volume, diffusion of $P$, convective movements and shaking before sampling contributed to the homogenization of the $\mathrm{P}$ solution concentration in the bottle. Consequently, the $P$ concentration gradient from the film around the particles at the bottom of the bottle and the bulk solution was greater (and more $\mathrm{P}$ was released) the larger the $W$. This resulted in a positive value for $a$.

The value of $a$ ranges from 0.29 to 0.69 and is correlated with the degree of saturation of the 

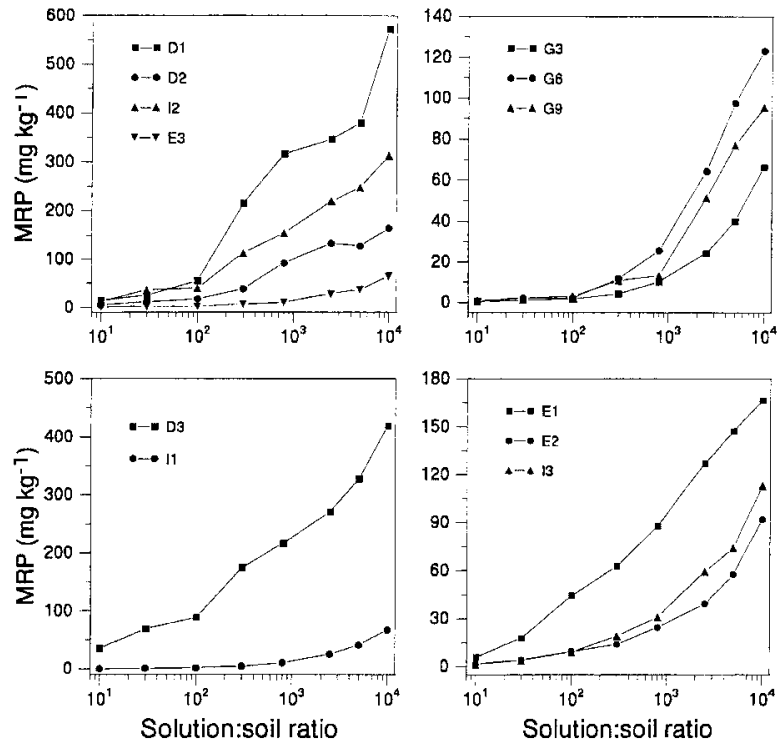

Figure 1. The amount of molybdate-reactive $P$ (MRP) released under static conditions at $340 \mathrm{~d}$ as a function of the solution/soil ratio $(W)$.

$\mathrm{P}$-adsorbing surfaces of the soil with $\mathrm{P}$. In this respect, an index of surface saturation with $P$ (ISSP, table I) can be defined, which is the ratio between the $P$ exchanged isotopically over 1 day $\left(\mathrm{IEP}_{1}\right)$ and the PACI defined above. IEP is used $_{1}$ for this purpose as a measure of labile $P$ and is mainly (but not exclusively) 'surface $\mathrm{P}$ ', i.e. $\mathrm{P}$ in the form of phosphate adsorbed on the P-reactive soil surfaces [14]. The negative correlation between $a$ and ISSP (figure 2) indicates that the higher the degree of saturation of the surface with $\mathrm{P}$, the higher the proportion of $\mathrm{P}$ released at low relative to high $W$ values. This is probably related to the different affinities with which $\mathrm{P}$ is adsorbed. The soils with high ISSP $(>0.8)$, i.e. with a higher proportion of $\mathrm{P}$ on low-affinity sites, release, relative to the other soils, significant amounts of $\mathrm{P}$ without so much need to increase $W$ (which results in a lower solution $\mathrm{P}$ concentration and greater $\mathrm{P}$ concentration gradients). The lowest $a$ values (0.29-033) are observed for soils D1, D2, D3, E1 and $\mathrm{I}$, which show high ISSP values. In addition, previous studies $[7,16]$ suggest that these soils

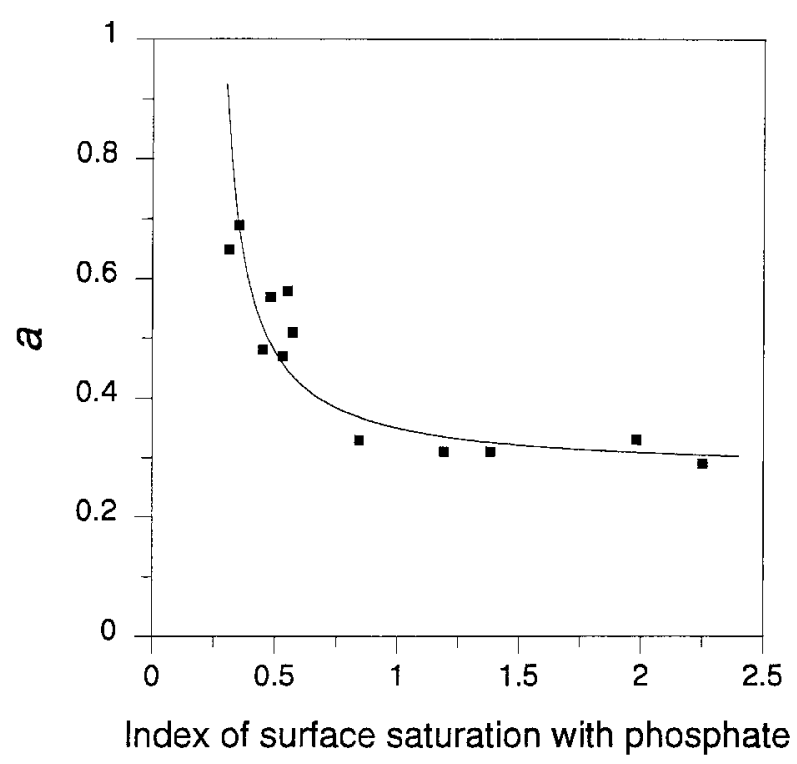

Figure 2. Relationship between the exponent $a$ in equation (2) and the index of surface saturation with P (ISSP). The line is drawn to help the reader's eye.

contain relatively large amounts of soluble $\mathrm{Ca}$ and Ca-containing metal phosphates. These phosphates apparently buffer the $\mathrm{P}$ solution concentration at values of $10^{-6}-10^{-5} \mathrm{M}$. Thus, substantial amounts of $\mathrm{P}$ are released at low relative to high $W$ values.

High (>0.48) a values are observed for soils E2, E3, G3, G6, G9 and I1, which show low $(<0.8)$ ISSP values. In these soils, increase in $W$ and consequent dilution of the suspension favours release of $\mathrm{P}$ compared to the soils rich in $\mathrm{Ca}$ phosphates, the likely reason being the higher affinity with which $\mathrm{P}$ is retained at low ISSP values. Interestingly, two of the calcareous soils (E2 and 13) show high $a$ values ( 0.48 and 0.47 , respective1y), despite that fertilization is expected to have resulted in precipitation of $\mathrm{Ca}$ phosphates as, for example, in E1, the other calcareous soil. The reason is probably the low solubility of the Ca phosphates in these two soils, as extraction with resin suggested [7].

The value of $a$ is positively correlated with $\mathrm{Fe}_{\mathrm{d}}$ $\left(r=0.689^{*}\right) ; \mathrm{Fe}_{\mathrm{o}}+\mathrm{Al}_{\mathrm{o}}\left(r=0.585^{*}\right), \mathrm{Al}_{\mathrm{d}}$ 


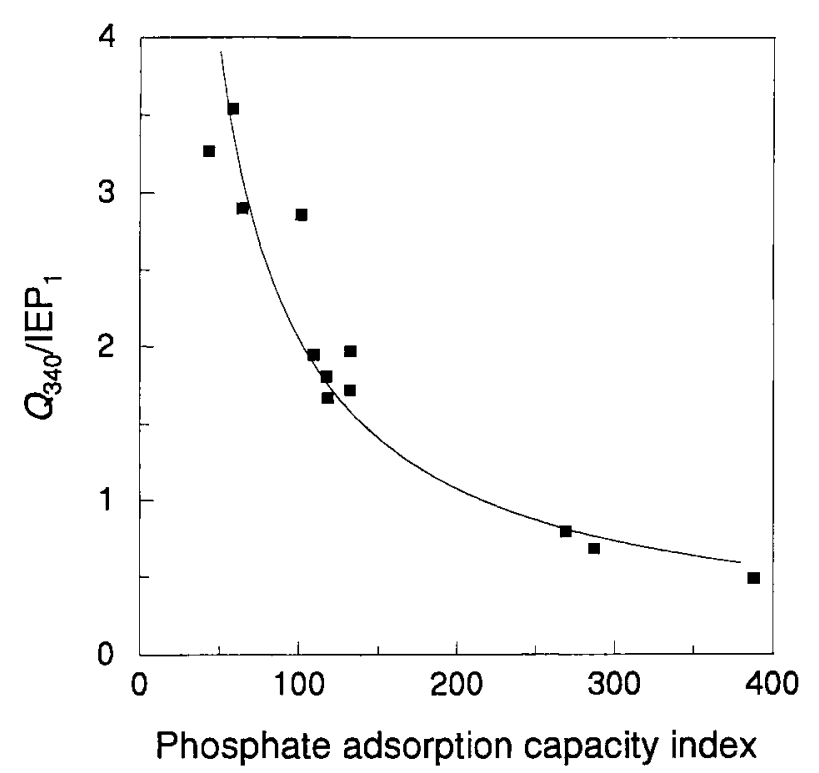

Figure 3. Relationship between the $Q_{340} / \mathrm{IEP}_{1}$ ratio and the $\mathrm{P}$ adsorption capacity index (PACI). $Q_{340}$ is the P released under static conditions for $W=10000$ at $340 \mathrm{~d}$ and IEP is the $\mathrm{P}$ exchanged isotopically at 1 day. The line is drawn to help the reader's eye.

$(r=0.592 *)$ and $\mathrm{Al}_{\mathrm{o}}(r=0.611 *)$, i.e. $a$ increases with increasing $\mathrm{P}$ adsorption capacity of the soil. However, this relationship may be due to the PACI-ISSP covariance, in as much as the soils with the highest $P$ sorption capacity (G3, G6, G9 and I1) also show some of the lowest ISSP values.

Differences in the value of the exponent $b$ (which is always significantly different from zero) are small, which indicates that the time course of $\mathrm{P}$ release is not significantly affected by soil properties and $\mathrm{P}$ forms.

The ratio between $P$ released at $340 \mathrm{~d}$ and $W=10000$ and $\mathrm{IEP}_{1}\left(\mathrm{Q}_{340} / \mathrm{IEP}_{1}\right.$, table III $)$ is correlated with the PACI (figure 3). G3, G6 and G9, which are the soils with the highest adsorption capacity and low surface saturation index, show $\mathrm{Q}_{340} / \mathrm{IEP}_{1}$ values $<1$, i.e. not all the $\mathrm{IEP}_{1}$ is released after $340 \mathrm{~d}$ to a solution with low $\mathrm{P}$ concentration (high $W$ value). This indicates that $\mathbf{P}$ released at $340 \mathrm{~d}$ is essentially surface $P$ that is desorbed from only part of the high affinity sites.

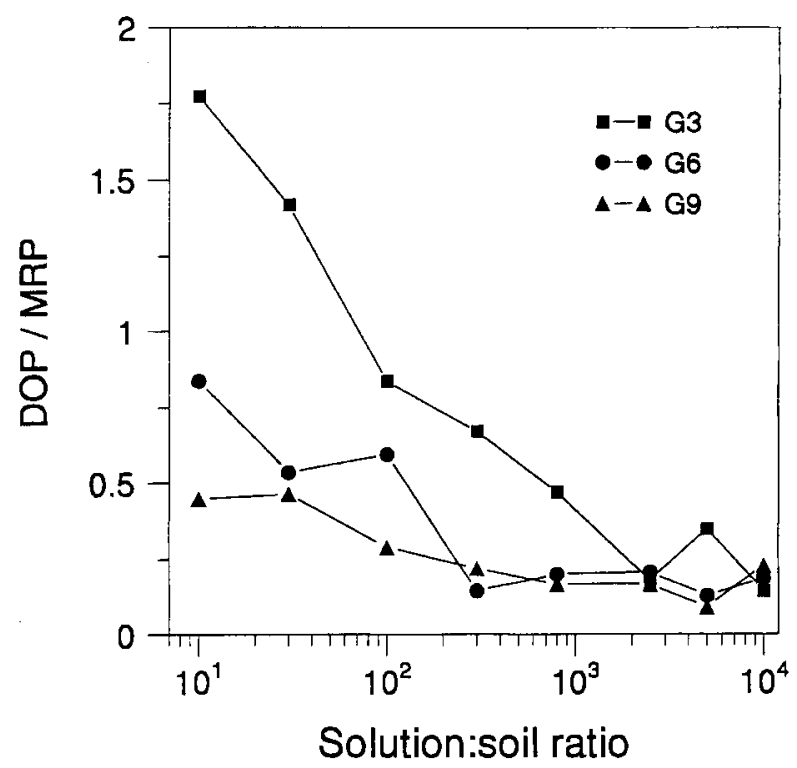

Figure 4. Relationship between the ratio (dissolved organic P)/(molybdate-reactive P) (DOP/MRP) and the solution/soil ratio $(W)$ for the three acid soils rich in organic matter.

In contrast, D1, D3 and $\mathrm{E} 1$ show $\mathrm{Q}_{340} / \mathrm{IEP}_{1}$ ratios $>2.5$, suggesting that not only desorption of adsorbed $\mathrm{P}$ but dissolution of soluble metal phosphates plays a significant role in $P$ release. This is consistent with the high amounts in readily soluble metal phosphates that these soils contain. We can conclude: a) that $\mathrm{IEP}_{1}$ is a poor indicator of the $\mathrm{P}$ that can be released from the soil at high $W$ values and long times; and $b$ ) that the $\mathrm{Q}_{340} / \mathrm{IEP}_{1}$ ratio seems determined by the main process (dissolution or desorption) involved in the release of $\mathrm{P}$ to water.

Dissolved organic $\mathrm{P}$ (DOP) has been reported as an important fraction of the total $P$ released by some soils; this is logical since DOP occurs in the solution of some soils of temperate humid regions in amounts comparable to MRP [6]. In our experiments, release of DOP in substantial amounts occurred in the acid soils with high organic matter content, where the amount of DOP released doubled that of MRP at low $W$ values (figure 4 ). The amount of DOP released increased with increasing 
$W$, suggesting that the release of DOP is partly due to desorption from adsorbed organic $\mathrm{P}$ forms. This is consistent with the capacity of major chemical forms of DOP in soils to bind to positively charged sites on soil surfaces through ligand exchange with reactive surface hydroxyls $[13,22]$. Our experiments also showed that the DOP/MRP ratio decreased with increasing $W$, suggesting that $\mathrm{DOP}$ forms tend to be, on average, less firmly bound to surfaces than (ortho)phosphate ions. Thus, they are more readily released than MRP at small $W$ values.

\subsection{Short-term $P$ release under turbulent conditions}

The release of $\mathrm{P}$ to solution under turbulent conditions could also be described with an equation analogous to equation (1), expressed as:

$$
Q=T W^{d} t^{e}
$$

where $T, d$ and $e$ are constants for each soil. For $t$ expressed in minutes, the values of the equation constants (which were always significantly different from zero) are given in table IV.T is the fitted amount of $P$ released at 1 min for $W=1$. It mimics, in this respect, the $\mathrm{P}$ released immediately after rainwater enters into contact with soil in highly tur- bulent conditions. The $\mathrm{P}$ released at $t=120 \mathrm{~min}$ $(2 \mathrm{~h})$ and high $W$ values mimics the $\mathrm{P}$ released after transportation of soil particles in surface runoff and stream water. In the studied soils, the amount of $P$ released after $2 \mathrm{~h}$ at $W=10000$ represents between 7 and $27 \%$ of the amount of $P$ released at $340 \mathrm{~d}$ in static conditions for the same value of $W\left(\mathrm{Q}_{2 \mathrm{~h}} / \mathrm{Q}_{340}\right.$ ratio; table $I V$ ) indicating that turbulent mixing during surface runoff and stream transport play a substantial role in increasing $\mathrm{P}$ concentration in water.

In soils poor in $\mathrm{P}$ the initial amount of $\mathrm{P}$ released at the soil site $(T)$ can be higher than the final amount of $P$ released to runoff since $P$ re-adsorption by sediments is possible $[20,24]$. In all the soils we studied, the amount of $P$ released after $2 \mathrm{~h}$ at $W=10000$ was greater than $T$. Soils known to contain substantial amounts of soluble metal phosphates (D1, D2, D3, I2) were the soils that released more $\mathrm{P}$ at $2 \mathrm{~h}$ (high released to total $\mathrm{P}$ ratio). In these soils, the release of $\mathrm{P}$ is noticeable even at low $W$ values.

The $\mathrm{Q}_{2 \mathrm{~h}} / \mathrm{IEP}$, ratio for $W=10000$ (table $I V$ ) is negatively correlated with $\mathrm{Fe}_{\mathrm{o}} / \mathrm{Fe}_{\mathrm{d}}$ and $\left(\mathrm{Fe}_{\mathrm{o}}+\right.$ $\mathrm{Al}_{\mathrm{o}}$ )/clay (figure 5). These correlations indicate that the proportion of surface $\mathrm{P}$ that is released to turbulent aquatic systems decreases as the poorly

Table IV. P released under turbulent conditions.

\begin{tabular}{|c|c|c|c|c|c|c|c|}
\hline Soil & $\begin{array}{c}T^{\mathrm{a}} \\
\left(\mathrm{mg} \mathrm{P} \mathrm{kg}^{-1}\right)\end{array}$ & $d^{\mathrm{a}}$ & $e^{a}$ & $R^{2}$ & $\begin{array}{c}\text { P released at } 2 \mathrm{~h} \text { for } \\
W=10000\left(Q_{2 \mathrm{~h}}\right)\left(\mathrm{mg} \mathrm{kg}^{-1}\right)\end{array}$ & $Q_{2 \mathrm{~h}} / Q_{340}^{\mathrm{b}}$ & $Q_{2 h} / \mathrm{IEP}_{1}$ \\
\hline D1 & 7.35 & $0.11 \mathrm{c}$ & $0.35 c$ & $0.85^{* * * 3}$ & 104 & 0.18 & 0.35 \\
\hline D2 & 2.05 & $0.13 \mathrm{~cd}$ & $0.34 c$ & $0.83^{* * * * *}$ & 29 & 0.18 & 0.16 \\
\hline D3 & 7.20 & $-0.04 \mathrm{a}$ & $0.38 \mathrm{c}$ & $0.86^{* * * *}$ & 28 & 0.07 & 0.07 \\
\hline E1 & 0.77 & $0.28 \mathrm{f}$ & $0.35 \mathrm{c}$ & $0.88^{* * * *}$ & 45 & 0.27 & 0.45 \\
\hline E2 & 0.23 & $0.36 \mathrm{~h}$ & $0.18 b$ & $0.95^{* * *}$ & 14 & 0.15 & 0.22 \\
\hline E3 & 0.09 & $0.43 \mathrm{j}$ & $0.19 b$ & $0.81^{\text {***** }}$ & 13 & 0.20 & 0.23 \\
\hline G3 & 0.10 & $0.40 \mathrm{i}$ & $0.2 \mathrm{lb}$ & $0.80^{\text {**** }}$ & 11 & 0.17 & 0.02 \\
\hline G6 & 1.04 & $0.14 \mathrm{de}$ & $0.32 \mathrm{c}$ & $0.72^{* * * *}$ & 20 & 0.16 & 0.03 \\
\hline G9 & 0.34 & $0.32 \mathrm{~g}$ & $0.19 b$ & $0.63^{* * * *}$ & 18 & 0.19 & 0.03 \\
\hline I1 & 0.02 & $0.64 \mathrm{k}$ & $0.12 \mathrm{a}$ & $0.75^{* * * *}$ & 16 & 0.11 & 0.09 \\
\hline I2 & 4.82 & $0.04 b$ & $0.31 c$ & $0.78^{* * * * *}$ & 30 & 0.10 & 0.10 \\
\hline I3 & 0.68 & $0.16 \mathrm{e}$ & $0.32 c$ & $0.80^{* * * *}$ & 14 & 0.12 & 0.11 \\
\hline
\end{tabular}

a Constants of the equation $Q=T W^{d} t^{e}$, where $W$ is the solution/soil ratio and $t$ is time in minutes. Values followed by the same letter in the same column are not significantly different $(P<0.05)$.

${ }^{\mathrm{b}}$ For $W=10000$. 

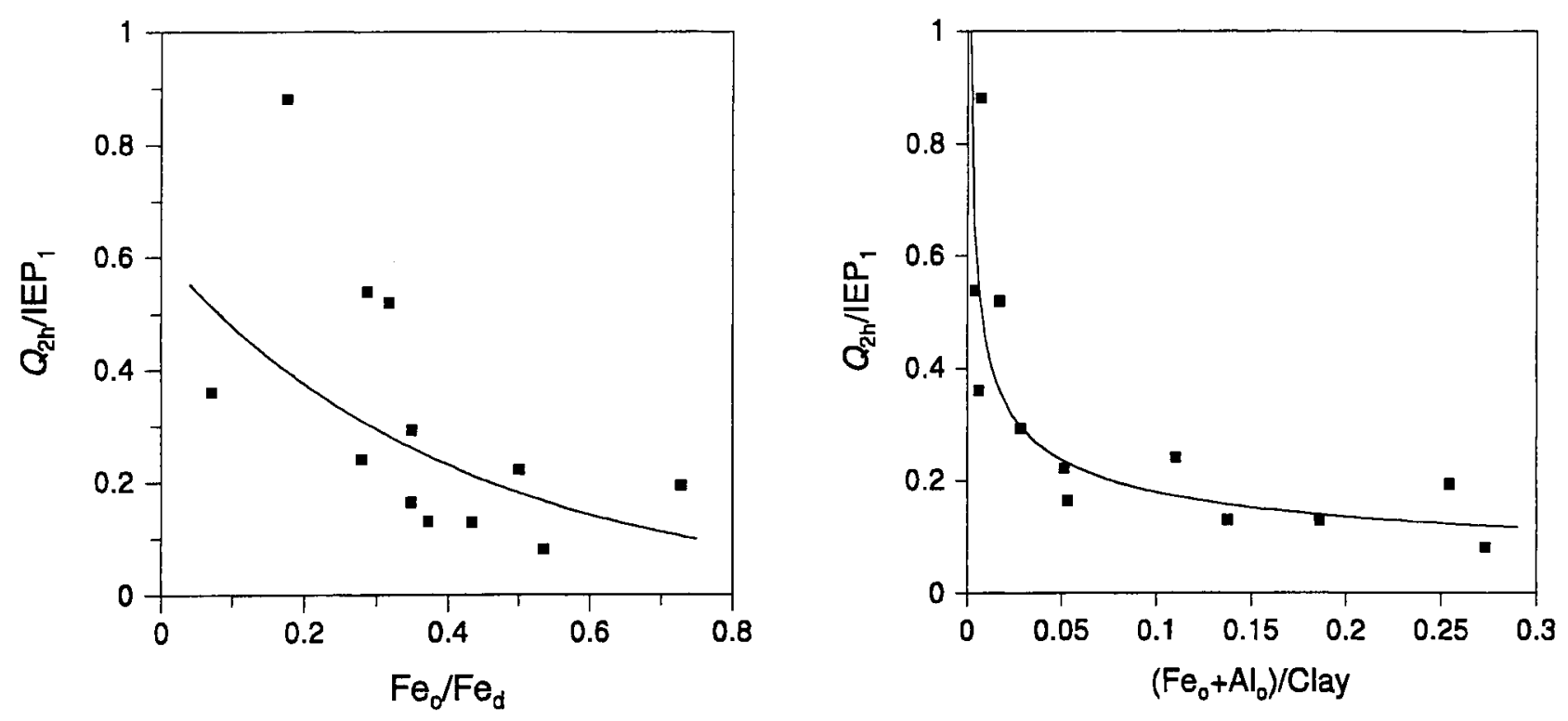

Figure 5. Relationship between the ratio $Q_{2 h} / I E P_{1}$ and the $\mathrm{Fe}_{0} / \mathrm{Fe}_{\mathrm{d}}$ and $\left(\mathrm{Fe}_{0}+\mathrm{Al}_{\mathrm{o}}\right) / \mathrm{clay}$ ratios. $\mathrm{Q}_{2 \mathrm{~h}}$ is the amount of $\mathrm{P}$ released at $2 \mathrm{~h}$ under turbulent conditions for $W=10000$. The line is drawn to help the reader's eye.

crystalline $\mathrm{Fe}$ and $\mathrm{Al}$ oxides represent an increasing proportion of the P-adsorbing surfaces. These correlations are the result of the slow diffusion of $\mathrm{P}$ observed in poorly crystalline oxides $[5,26]$. We can conclude that soils with high $P$ adsorption capacity and high poorly crystalline $\mathrm{Fe}$ and $\mathrm{Al}$ oxides contents have less short-term capacity to release $P$ to surface runoff and stream water.

\section{Conclusions}

The release of molybdate-reactive $\mathrm{P}$ (MRP) from soil to a dilute electrolyte under static or turbulent conditions could be described by a potential function of the solution/soil ratio $(W)$ and time. The ratio between MRP released at $340 \mathrm{~d}$ and $W=10000$ and $\mathrm{P}$ exchanged isotopically at $1 \mathrm{~d}$ was the highest in the soils where excessive $\mathrm{P}$ fertilizer application had resulted in the precipitation of relatively soluble metal phosphates and the lowest in soils with a low degree of saturation with $\mathrm{P}$ (acid soils with high $\mathrm{P}$ adsorption capacity). With increasing $W$, a larger increase in the amount of MRP released was observed in the latter relative to the former soils. The amounts of dissolved organic $\mathrm{P}$ (DOP) and MRP released to the electrolyte were comparable in the acid soils rich in organic matter.

From 7 to $27 \%$ of the amount of $P$ released at $340 \mathrm{~d}$ and $W=10000$ was released in only $2 \mathrm{~h}$ of turbulent conditions. The rate of $\mathrm{P}$ release under these conditions decreased with increasing proportion of poorly crystalline $\mathrm{Fe}$ and $\mathrm{Al}$ oxides relative to other P-adsorbing soil constituents.

In summary, our results indicate that the release of soil $\mathrm{P}$ to a dilute electrolyte is greatly influenced by the nature of soil constituents and $P$ forms. Therefore, appropriate prediction of the amount of $P$ released under different conditions must be based on a careful consideration of soil properties.

Acknowledgements: This work was funded by the European Union (Contract AIR CT92-0303).

\section{References}

[1] Abrams M.M., Jarrell W.M., Soil phosphorus as a potential nonpoint source for elevated stream phosphorus level, J. Environ. Qual. 24 (1995) 132-138. 
[2] American Public Health Association, American Water Works Association and Water Pollution Control Federation, Standard methods for the examination of water and wastewater, 15th Ed., Am. Public Health Assoc., Washinton DC, 1980.

[3] Barberis E., Ajmone-Marsan F., Scalenghe R., Lammers A., Schwertmann U., Edwards A.C., Maguire R., Wilson M.J., Delgado A., Torrent J., European soils overfertilized with phosphorus: Part 1. Basic properties, Fertil. Res. 45 (1996) 199-207.

[4] Behrendt H., Boekhold A., Phosphorus saturation in soils and groundwaters, Land Degradation and Rehabilitation 4 (1993) 233-243.

[5] Cabrera F., de Arambarri P., Madrid L., Toca C.G., Desorption of phosphate from iron oxides in relation to equilibrium $\mathrm{pH}$ and porosity, Geoderma 26 (1984) 203-216.

[6] Chardon W.J., Oenema O., del Castilho P., Vriesema R., Japenga J., Blaauw D., Organic phosphorus in solutions and leachates from soils treated with animal slurries, J. Environ. Qual. 26 (1997) 372-378.

[7] Delgado A., Liberación de fosfato en suelos sobrefertilizados de la Unión Europea, Tesis Doctoral, Universidad de Córdoba, 1996.

[8] Delgado A., Torrent J., Phosphate-rich soils in the European Union: estimating total plant-available phosphorus, Eur. J. Agron. 6 (1997) 205-214.

[9] Gartley K.L., Sims J.T., Phosphorus soil testing: environmental uses and implications, Commun. Soil. Sci. Plant. Anal. 25 (1994) 1565-1582.

[10] Hawkins J.M.B., Scholefield D., Molybdatereactive phosphorus losses in surface and drainage waters from permanent grassland, J. Environ. Qual. 25 (1996) 727-732.

[11] Kronvang B., The export of particulate matter, particulate phosphorus and dissolved phosphorus from two agricultural river basins: implications on estimating the non-point phosphorus load, Water Res. 26 (1992) 1347-1358.

[12] Murphy J., Riley J.P., A modified single solution method for determination of phosphate in natural waters, Anal. Chim. Acta. 27 (1962) 31-36.

[13] Oganalaga M., Frossard E., Thomas F., Glucose1-phosphate and myo-inositol hexaphosphate adsorption mechanism on goethite, Soil Sci. Soc. Am. J. 58 (1994) 332-337.

[14] Olsen S.R., Khasawneh F.E., Use and limitations of physical-chemical criteria for assessing the status of phosphorus in soils, in: Khasawneh F.E., Sample E.C., Kamprath E.J. (Eds.), The Role of Phosphorus in Agriculture, ASA, Madison, WI, 1980, pp. 361-410.
[15] Olsen S.R., Sommers L.E., Phosphorus, in: Page A.L., Miller R.H., Keeney D.R., (Eds.), Methods of Soil Analysis, 2nd ed., Part 2, ASA and SSSA, Madison, WI, 1982, pp. 403-430.

[16] Ruiz J.M., Delgado A., Torrent J., Iron-related phosphorus in overfertilized European soils, J. Environ. Qual. 26 (1997) 1548-1554.

[17] Sharpley A.N., Effect of soil properties on the kinetics of phosphorus desorption, Soil Sci. Soc. Am. J. 47 (1983) 462-467

[18] Sharpley A.N., Smith S.J., Phosphorus transport in agricultural runoff: the role of soil erosion, in: Boardman J., Foster D.L., Dearing J.A. (Eds.), Soil Erosion on Agricultural Land, John Wiley and Sons, New York, 1990, pp. 35I-366.

[19] Sharpley A.N., Ahuja L.R., Menzel R.G., The release of soil phosphorus to runofff in relation to the kinetics of desorption, J. Environ. Qual. 101981 , 386-391.

[20] Sharpley A.N., Menzel R.G., Smith S.J., Rhoades E.D., Olness A.E., The sorption of soluble phosphorus by soil material during transport in runoff from cropped and grassed watersheds, J. Environ. Qual. 10 (1981) 211-215.

[21] Sharpley A.N., Daniel T.C., Edwards D.R., Phosphorus movement in the landscape, J. Prod. Agric. 6 (1993) 492-500.

[22] Stewart J.W.B., Tiessen H., Dynamics of soil organic phosphorus, Biogeochemistry 4 (1987) 41-60.

[23] Stumm W., Morgan J.J., Aquatic Chemistry, Wiley-Interscience, New York, 1970.

[24] Taylor A.W., Kunishi H.M., Phosphate equilibria on stream sediment and soil in a watershed draining an agricultural region, J. Agric. Food. Chem. 19 (1971) $827-831$.

[25] Torrent J., Interactions between phosphate and iron oxide, in: Soils and the Environment (Advances in Geoecology 30), Catena Verlag, Reiskirchen, 1997, pp. 321-344.

[26] Torrent J., Schwertmann U., Barrón V., Fast and slow phosphate sorption by goethite-rich materials, Clay Clay Miner. 40 (1992) 14-21.

[27] Vaithiyanathan P., Correl D.L., The Rhode river watershed: phosphorus distribution and export in forest and agricultural soils, J. Environ. Qual. 21(1992) 280-288.

[28] Weaver D.M., Managing the nutrient losses from rural sources and urban environments, Fertil. Res. 36 (1993) 165-170. 